\title{
Sikeres extracorporalis membránoxigenizációs (ECMO-) kezelés Legionella-pneumoniában
}

\author{
Madurka Ildikó dr. ${ }^{1}$ - Bartók Tibor dr. ${ }^{1}$ - Kormosói-Tóth Krisztina dr. ${ }^{1}$ \\ Schönauer Nóra dr. ${ }^{1}$ - Elek Jenő dr. ${ }^{1}$ - Bobek Ilona dr. ${ }^{2}$ \\ ${ }^{1}$ Országos Onkológiai Intézet, Aneszteziológiai és Intenzív Terápiás Osztály, Budapest \\ ${ }^{2}$ Dél-pesti Centrumkórház - Országos Hematológiai és Infektológiai Intézet, \\ Központi Aneszteziológiai és Intenzív Betegellátó Osztály, Budapest
}

\begin{abstract}
A súlyos akut légzési elégtelenség (ARDS) mortalitása elérheti a 60\%-ot. A lélegeztetéssel összefüggő további tüdőkárosodás mértéke csökkenthetố alacsony légúti nyomások és térfogatok alkalmazásával. A korszerű lélegeztetés ellenére fennálló hypoxaemia esetében felmerül az extracorporalis membránoxigenizáció lehetősége. A respirációs indikációval végzett kezelések száma világszerte nő, bár hatékonyságuk még nem egyértelmúen bizonyított. Beszámolunk az Intézetünkben végzett sikeres, első venovenosus ECMO (VV ECMO-) kezeléssel ellátott ARDS-ről. Hatvanhét éves férfi közösségben szerzett tüdőgyulladásának hátterében Legionellát igazoltak. Empirikus, majd célzott antibiotikumterápia ellenére súlyos ARDS, szepszis alakult ki. Respiráltatással nem sikerült kielégítő oxigenizációt elérni, a hasra fordítás is csak átmeneti javulást hozott. A beteget áthelyezték Intézetünkbe potenciális extracorporalis 'life support' (ECLS-) terápia céljából. A felvételi vérgáz súlyos hypoxaemiát, enyhe hypercapniát mutatott, $\mathrm{PaO}_{2} / \mathrm{FiO}_{2}$ : 60, $\mathrm{PaCO}_{2}: 53 \mathrm{Hgmm}$, PEEP: $14 \mathrm{Hgmm}$, PIP: $45 \mathrm{Hgmm}$ respirációs paraméterek mellett. A mellkasröntgenen kétoldali gócos infiltrátumot, a szívultrahangon csökkent balkamra-funkciót (45\%), tágabb jobb kamrát láttunk, emelkedett pulmonalis artériás nyomást mértünk (mPAP: $41 \mathrm{Hgmm})$. Femorojugularis venovenosus ECMO-kezelést indítottunk. Tüdőprotektív $\left(\mathrm{FiO}_{2}: 0,5, \mathrm{TV}: 3-4 \mathrm{ml} / \mathrm{ttkg}\right.$ ) lélegeztetés mellett a vérgázértékek az alkalmazott $\mathrm{VV}$ ECMO-technika elvárásainak megfelelően alakultak. 8 nap VV ECMO-kezelés után, további 5 nap alatt leszoktattuk a beteget a lélegeztetőgépről. Összességében 21 nap intenzív terápiát követően visszahelyeztük a küldő intézetbe, ahonnan rehabilitációt követóen otthonába távozott. A fenti eset ismertetésével szeretnénk felhívni a figyelmet a respirációs indikációjú ECMO-kezelések jelentőségére, hogy ezek a kezelések a külföldi gyakorlathoz hasonlóan nagyobb teret nyerhessenek a hazai intenzív terápiás gyakorlatban.
\end{abstract}

Orv Hetil. 2019; 160(6): 235-240.

Kulcsszavak: pneumonia, ARDS, venovenosus ECMO, ECLS

\section{Successful extracorporeal membrane oxygenation (ECMO) treatment in Legionella pneumonia}

The mortality of severe ARDS is almost $60 \%$. Ventilation-associated lung-injury can be avoided by low-pressure, lowvolume ventilation. Potential use of ECMO in case of refractory hypoxemia beside modern ventilatory therapy can be considered. Increasing numbers of respiratory ECMO runs are seen worldwide, though the efficacy remains controversial. The authors present the first successful venovenous-ECMO treatment in severe ARDS in our Institute. We report the case of a 67-year-old male who was admitted with community-acquired pneumonia caused by Legionella. Despite empirical and later targeted antibiotic therapy, severe ARDS with sepsis evolved. Neither ventilation nor prone position resulted in permanent improvement in oxygenation. The patient was referred to our Institute for extracorporeal life support (ECLS) therapy. On admission, blood gas showed severe hypoxemia with mild hypercapnia $\left(\mathrm{PaO}_{2} / \mathrm{FiO}_{2}: 60, \mathrm{pCO}_{2}: 53 \mathrm{mmHg}\right.$ at PEEP: $14 \mathrm{mmHg}$, PIP: $\left.45 \mathrm{mmHg}\right)$. X-ray showed bilateral patchy infiltrates while cardiac impairment (EF: $45 \%$ ) and dilated right ventricle were seen on echocardiography. Elevated pulmonary artery pressure (mPAP: $41 \mathrm{mmHg}$ ) was measured. After implantation of femoral-jugular VV ECMO, oxygen saturation was appropriate with lung protective ventilation $\left(\mathrm{FiO}_{2}: 0.5, \mathrm{TV}: 3-4 \mathrm{ml} / \mathrm{kg}\right)$. Improving lung function enabled us to stop ECMO after 8 days and further 5 days later the patient was weaned off ventilation. After 21 days 
of intensive care we discharged him to the referral hospital. By reporting this case we emphasise the potential role of respiratory ECMO. Consideration should be given to increase the contingent of this modality in the Hungarian intensive care in accordance with international practice.

Keywords: pneumonia, ARDS, venovenous ECMO, ECLS

Madurka I, Bartók T, Kormosói-Tóth K, Schönauer N, Elek J, Bobek I. [Successful extracorporeal membrane oxygenation (ECMO) treatment in Legionella pneumonia]. Orv Hetil. 2019; 160(6): 235-240.

(Beérkezett: 2018. augusztus 26.; elfogadva: 2018. október 1.)

\section{Rövidítések}

ACT $=$ (activated clotting time $)$ aktivált alvadási idő; AOI = (age-adjusted oxygenation index) életkorhoz igazított oxigenizációs index; APPS $=\left(\right.$ age, $\mathrm{PaO}_{2} / \mathrm{FiO}_{2}$, Pplat score $)$ életkor, $\mathrm{PaO}_{2} / \mathrm{FiO}_{2}$, platónyomáspont; ARDS = (acute respiratory distress syndrome) heveny légzési elégtelenség szindróma; CI $=($ cardiac index $)$ szívindex $; \mathrm{CRP}=\mathrm{C}$-reaktív protein; $\mathrm{CT}=$ (computed tomography) számítógépes tomográfia; $\mathrm{DO}_{2}=$ (oxygen delivery) oxigénszállítás; DPC = Dél-pesti Centrumkórház; ECLS = (extracorporeal life support $)$ extracorporalis 'life support' (kezelés); ECMO = (extracorporeal membrane oxygenation) extracorporalis membránoxigenizáció; ELSO = Extracorporeal Life Support Organisation; $\mathrm{FiO}_{2}=$ (fraction of inspired oxygen concentration) belélegzett levegő oxigénkoncentrációja; HPV = (hypoxic pulmonary vasoconstriction) hypoxiás pulmonalis vasoconstrictio; KAIBO = Központi Aneszteziológiai és Intenzív Betegellátó Osztály; LDH = laktátdehidrogenáz; LVEF $=$ (left ventricle ejection fraction $)$ balkamrai ejekciós frakció; $\mathrm{mPAP}=($ mean pulmonary arterial pressure) pulmonalis artériás középnyomás; mrtg $=$ mellkasröntgen; OOI = Országos Onkológiai Intézet; $\mathrm{PCT}=$ prokalcitonin; $\mathrm{POC}=$ (point-of-care) ágy melletti laborvizsgálat; $\mathrm{RR}$ $=($ respiratory rate $)$ légzésszám; $\mathrm{SvO}_{2}=($ mixed venous oxygen saturation) kevert vénás oxigénszaturáció; TTE $=$ (transthoracic echocardiogram) transthoracalis szívultrahang; ttkg = testtömegkilogramm; TV = (tidal volume) légzési térfogat; $\mathrm{UH}=$ ultrahangvizsgálat; $\mathrm{VA}=($ venoarterial $)$ venoarteriosus; $\mathrm{VALI}=$ (ventilation-associated lung injury) lélegeztetéshez társuló tüdőkárosodás; V-AV = (veno-arteriovenous) venoarteriovenosus; $\mathrm{VV}=$ (venovenous) venovenosus

A közelmúltban megjelent LUNG SAFE vizsgálat 4 hetes adatgyújitése során, az 50 ország 454 intenzív osztályán vizsgált betegek 10,4\%-a (3022) felelt meg az ARDS berlini kritériumának. Ez az invazívan lélegeztetett betegek negyedét jelentette $[1,2]$. Az Egyesült Államokban évi 190 000-re becsülik az ARDS gyakoriságát, és 74000 halálesetet tulajdonítanak a betegségnek [3]. A módosított berlini definíciót figyelembe véve, a mortalitás az ARDS súlyosságától függően változhat $27-45 \%$ között [4], de az igen súlyos ARDS mortalitása $\left(\mathrm{PaO}_{2} /\right.$ $\mathrm{FiO}_{2}<50$ ) elérheti a $60 \%$-ot is [5]. A lélegeztetéssel öszszefüggő további tüdőkárosodás mértéke csökkenthető alacsonyabb légúti nyomások (Pdrive $<16$ vízcm, Pplateau $<30$ vízcm) és térfogatok $(\mathrm{TV}<6 \mathrm{ml} / \mathrm{ttkg})$ alkal- mazásával. A korszerú lélegeztetés mellett fennálló hypoxaemia, korrigálhatatlan acidosis esetében felmerül az extracorporalis membránoxigenizáció mint 'rescue' megoldás. A respirációs indikációval végzett kezelések száma világszerte nő [6], bár hatékonyságuk továbbra is vita tárgya $[7,8]$.

Az első sikeres ECMO-kezelést ARDS-ben 1972-ben végezte Hill és csapata. Egy 24 éves politraumatizált páciensen alkalmaztak 75 órán keresztül megfelelően adaptált cardiopulmonalis bypasst [9].

Az 1979-ben [10] és 1994-ben [11] megjelent két tanulmány, melyek az ECMO hatásosságát vizsgálták felnőttkori ARDS-ben, a gyermekkori alkalmazások eredményével ellentétben nem találták az ECMO alkalmazását kedvező hatásúnak a konvencionális terápiákkal szemben. Az ECMO-technika fejlődése, valamint az a felismerés, hogy a légzési elégtelenség ellátására elsődlegesen a venovenosus (VV-) ECMO alkalmas, és a 2009. évi $\mathrm{H}_{1} \mathrm{~N}_{1}$-pandémia indikálta nagyszámú ECMO-kezelés tapasztalata új lendületet adott a légzési elégtelenségben alkalmazott ECMO-terápiának. A Peek és mtsai által végzett vizsgálatban 2009-ben mutatták ki, hogy a VV ECMO a tüdôprotektív lélegeztetéssel együtt jobb túlélést biztosít a súlyos légzési elégtelenség ellátásában a konvencionális terápiával szemben [12]. A 2018-ban megjelent EOLIA (ECMO to rescue Lung Injury in Severe ARDS) vizsgálatban azonban a 60 napos mortalitás nem bizonyult szignifikánsan alacsonyabbnak a kontrollcsoporthoz viszonyítva. Érdemes hangsúlyozni, hogy a kontrollcsoportból a betegek 28\%-a végül ECMO-kezelésben részesült, és ebben az alcsoportban is a súlyosabb állapot ellenére több, mint $42 \%$-os volt a túlélés [7]. Az ECMO-centrumok száma 2017-re világszerte növekedett, megközelítette a 380-at, a kezelt esetek meghaladták az évi 10 000-ret. 2013 és 2018 júliusa között a felnőtt pulmonalis indikációjú regisztrált ECMO-eset-szám 11846 volt. A kezelések 68\%-ban tudták az ECMO-terápiát abbahagyni, a betegek $56 \%$-a távozott az ellátóosztályról [6].

A hazai morbiditási adatok bizonytalanok. A 2000. évi adatok alapján előfordulása 3/100 000 [13]. Az egyik nagy, nagyságrendileg 500000 beteg ellátására szervezett multidiszciplináris sürgősségi osztály 3 évét elemezve, közel 84000 felnőtt beteget láttak el. 4,5\% jelentke- 
zett légzőszervi panaszokkal. A 30 percen belüli ellátást indokló kritikus és sürgős esetek aránya átlagosan 23,4\% volt, míg a betegek 21\%-át hospitalizálták [14].

Hazánkban az alapvetően kardiológiai indikációjú ECMO-ról 2015-ben megjelent összefoglaló tanulmányban két esetet említenek, amelyeknél légzési elégtelenség ellátására ECMO-t alkalmaztak [15]. A cikk megjelenését követően számos esetben végeztek ECMOkezelést respirációs indikációval. Ugyanebben a cikkben foglalnak állást a szerzők a magyarországi ECMO-centrumok szervezési kérdéseiről, miszerint az akut/krónikus légzési elégtelenséget ellátó ECMO-centrum kialakítását a tüdőtranszplantációt végző központtal szoros együttmúködésben képzelik el.

\section{Esetismertetés}

A 67 éves férfi beteg anamnézisében penicillinérzékenység, 2-es típusú cukorbetegség, magas vérnyomás és pajzsmirigy-alulmúködés szerepelt. Belgyógyászati felvételére 1 hete tartó lázas állapot, köhögés, súlyos légszomj miatt került sor. A beteget a kétoldali atípusosnak tünő pneumonia talaján kialakult súlyos légzési elégtelenség $\left(\mathrm{PaO}_{2}: 42 \mathrm{Hgmm}\right.$, emelkedett laktátszint) miatt azonnal az intenzív osztályra helyezték át, ahol gépi lélegeztetést indítottak. Mellkasröntgenen (mrtg) kétoldali foltos transzparenciacsökkenést láttak, empirikusan cefalospo$\mathrm{rin} /$ makrolid antibiotikumterápiát vezettek be. Vizeletéből Legionella-antigént mutattak ki. Az eredmény birtokában a cefalosporint fluorokinolonra váltották. Mellkasröntgenen további progressziót észleltek, a lélegeztetés invazivitását növelve sem tudták kielégítően oxigenizálni. A 12 órás hasra fordítás csak átmeneti eredményt hozott, így ECLS-terápia céljából, 10 nap konzervatív respirátorkezelés után, a beteget osztályunkra helyezték át.

A felvételkor elvégzett CT-vizsgálat kétoldali kiterjedt infiltrátumot írt le kevés pleuralis folyadékkal (1. ábra). A beállított, agresszív lélegeztetési paraméterek mellett Horowitz-indexe $\left(\mathrm{PaO}_{2} / \mathrm{FiO}_{2}\right) 60$ volt. A transthoracalis szívultrahang (TTE)-vizsgálat csökkent balkamrafunkciót (LVEF: 40\%), a bevezetett pulmonalis katéter emelkedett pulmonalis nyomást $(50 / 20 \mathrm{Hgmm})$ és csökkent szívperctérfogat-indexet $\left(2,0 \mathrm{l} / \mathrm{min} / \mathrm{m}^{2}\right) \mathrm{mu}-$ tatott, a Murray-pontszám 3,75 volt. A fentiek alapján az ECMO indikációja fennállt, a relatív kontraindikációt a 7 napot meghaladó gépi lélegeztetés jelentette [16]. A jobb oldali vena (v.) femoralisba perkután 21 Fr-es (PVS 2138, Maquet Getinge Group, Rastatt, Németország), míg a jobb v. jugularisba 17 Fr-es (PAS 1715, Maquet Getinge Group) kanült vezettünk be, melyeken át az ECMO-kezelést elindítottuk. Az intravénás heparinterápiát ágy melletti point-of-care ACT-kontrollal irányítottuk, célértékként a 120-140 s-ot tartottuk. Sem a kanülálás, sem az ECMO-kezelés 8 napja alatt a fenti érték mellett vérzést nem észleltünk, az ECMO-körben alvadék nem keletkezett. Az antibiotikumterápiát rifam-

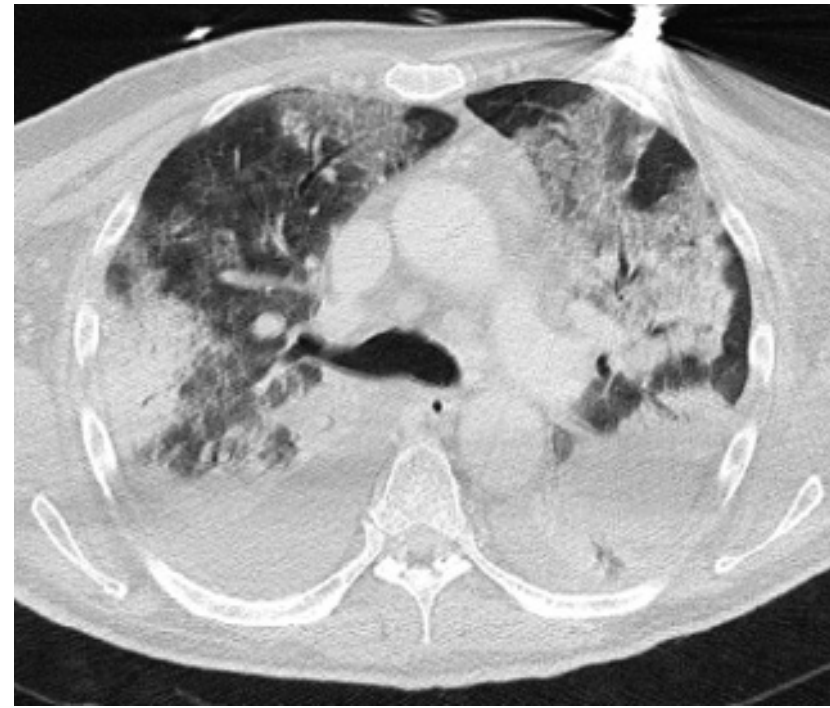

1. ábra | A felvételi akut mellkasi CT-n kiterjedt infiltrátum látható

picinnel egészítettük ki. A beteg követéséhez naponta több alkalommal végeztünk laborkontrollt (vérkép, CRP, PCT, máj- és vesefunkció, LDH, ACT, haptoglobin, D-dimer, vizelet vizsgálata). Ápolásunk alatt a beteg összesen 4 egység vért és 6 egység plazmát kapott, vérlemezke adására nem került sor. A 6. napon szövődménymentesen perkután légcsőmetszést végeztünk. A RESPpontszám [17] alapján számolt várható túlélés 40-60\% közé esett.

Az ECMO-kezelés indulásával párhuzamosan mérsékeltük a respiráció invazivitását. 3,3-3,5 literes ECMOáramlás, 3-4 ml/ttkg TV, 0,5-es $\mathrm{FiO}_{2}$ mellett az oxigenizáció jelentősen javult (1. táblázat). 12 óra múlva a szívperctérfogat emelkedett, a pulmonalis artériás nyo-

\begin{tabular}{l|l} 
1. táblázat & $\begin{array}{l}\text { Lélegeztetési paraméterek, szívindex }(\mathrm{CI}) \text {, artériás pulmonalis } \\
\text { átlagnyomás (mPAP), valamint a szérum-laktátszint változása a } \\
\text { VV ECMO indulása elótt és a VV ECMO-kezelés 24. órájában }\end{array}$
\end{tabular}

\begin{tabular}{lcc}
\hline & VV ECMO elótt & $\begin{array}{c}\text { Az ECMO indulása } \\
\text { után 24 órával }\end{array}$ \\
\hline Lélegeztetés & nyomáskontroll & nyomáskontroll \\
módja & 100 & 50 \\
$\mathrm{FiO}_{2}(\%)$ & 14 & 5 \\
$\mathrm{PEEP}($ vízcm $)$ & 31 & 10 \\
$\mathrm{PC}($ vízcm $)$ & 550 & 300 \\
$\mathrm{TV}(\mathrm{ml})$ & 15 & 10 \\
$\mathrm{RR}(\mathrm{l} / \mathrm{min})$ & 59 & 78 \\
\hline $\mathrm{PaO}(\mathrm{Hgmm})$ & 41 & 27 \\
$\mathrm{mPAP}(\mathrm{Hgmm})$ & 2,0 & 2,6 \\
$\mathrm{CI}\left(\mathrm{ml} / \mathrm{min} / \mathrm{m}^{2}\right)$ & 3,5 & 1,7 \\
$\mathrm{Laktát}(\mathrm{mmol} / \mathrm{l})$ & & \\
\hline
\end{tabular}

$\mathrm{CI}$ = szívindex $; \mathrm{ECMO}=$ extracorporalis membránoxigenizáció; $\mathrm{FiO}_{2}$ = belélegzett levegő oxigénaránya; $\mathrm{mPAP}=$ artériás pulmonalis középnyomás; $\mathrm{PaO}_{2}=$ artériás oxigéntenzió; PEEP = pozitív végkilégzési nyomás; RR = légzési frekvencia; TV = légzési térfogat; VV ECMO = venovenosus extracorporalis membránoxigenizáció 


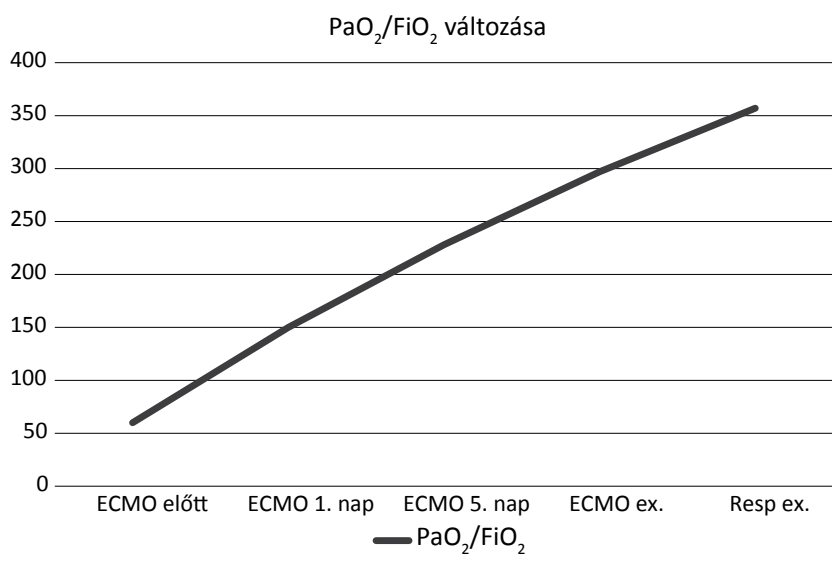

2. ábra

A $\mathrm{PaO}_{2} / \mathrm{FiO}_{2}$ változása az ECMO-kezelés során és a lélegeztetés befejezését követően

$\mathrm{Cl}\left(\mathrm{ml} / \mathrm{min} / \mathrm{m}^{2}\right)$ változása

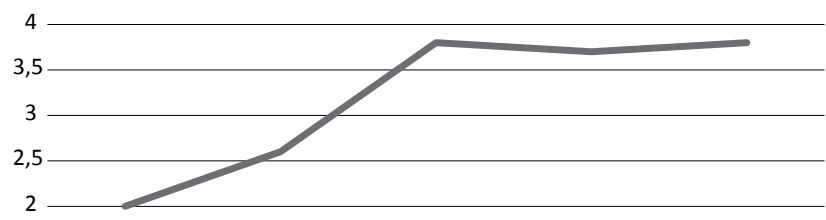

1,5

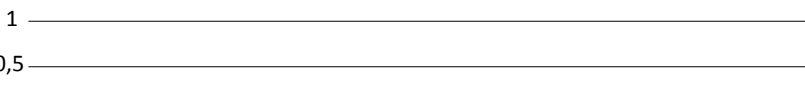

0 ECMO elött ECMO 1. nap ECMO 5. nap ECMO ex. Resp ex.

$$
\longrightarrow \mathrm{Cl}\left(\mathrm{ml} / \mathrm{min} / \mathrm{m}^{2}\right)
$$

3. ábra

A szívindex változása az ECMO-kezelés során és a lélegeztetés befejezését követően

más csökkent. Az ismételt szív-UH-vizsgálatok javuló balkamra-kontraktilitást mutattak.

A 2. és 3. ábrán látható a beteg paramétereinek javulása az idő függvényében. ECMO-kezelésünk 5. napjától jelentôs $\mathrm{PaO}_{2}$-emelkedést láttunk, melynek hátterében az ECMO oxigenizációs hatásán túl a javuló pulmonalis gázcsere állt (2. ábra). Érdekes tapasztalat, hogy mrtgen a javulás csak 3-4 nap késéssel jelentkezett (4. ábra). Kezelésünk 8. napján fokozatos áramláscsökkentés után sikeresen leállítottuk az ECMO-t. Dekanülálás után a punkciós helyeket 10 perc kompresszió után nyomókötéssel láttuk el. További 5 nap után a légzéstámogatást fokozatosan csökkentve, az elhagyhatóvá vált. Az ECMO-kezelés befejezését követően 13 nappal a beteget visszahelyeztük a küldő intézménybe, ahonnan hamarosan otthonába távozott (5. és 6. ábra).

\section{Megbeszélés}

A technikai fejlesztéseknek és a növekvő tapasztalatoknak köszönhetően a súlyos légzési elégtelenség ellátásában a megfelelő indikációval végzett ECMO-terápia életmentő eszköz lehet.

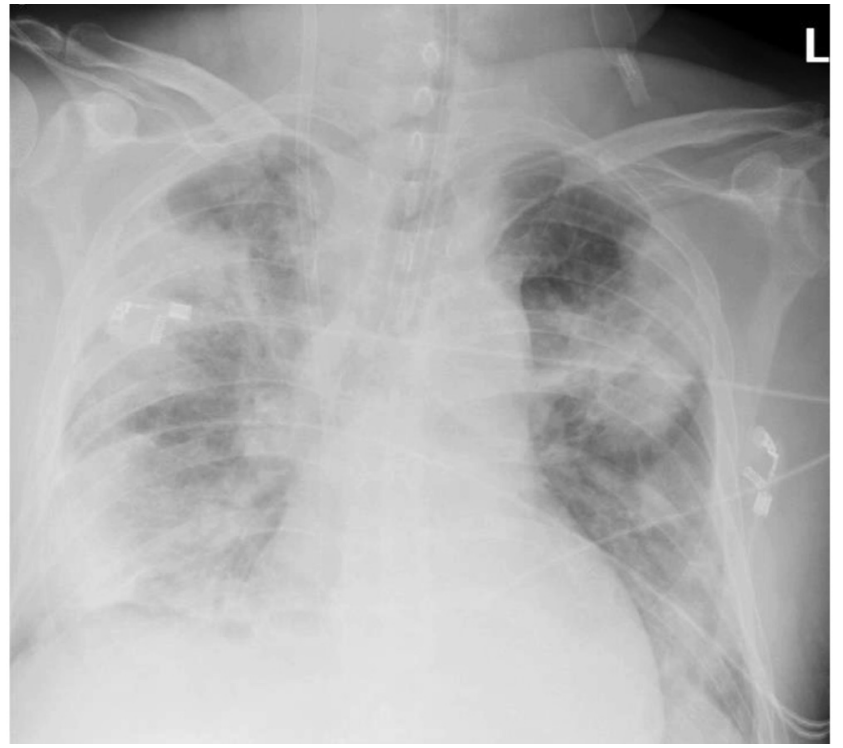

\begin{tabular}{l|l} 
4. ábra & $\begin{array}{l}\text { A helyszíni mellkasfelvételen a jobb oxigenizáció ellenére kevés } \\
\text { javulás látszik }\end{array}$
\end{tabular}

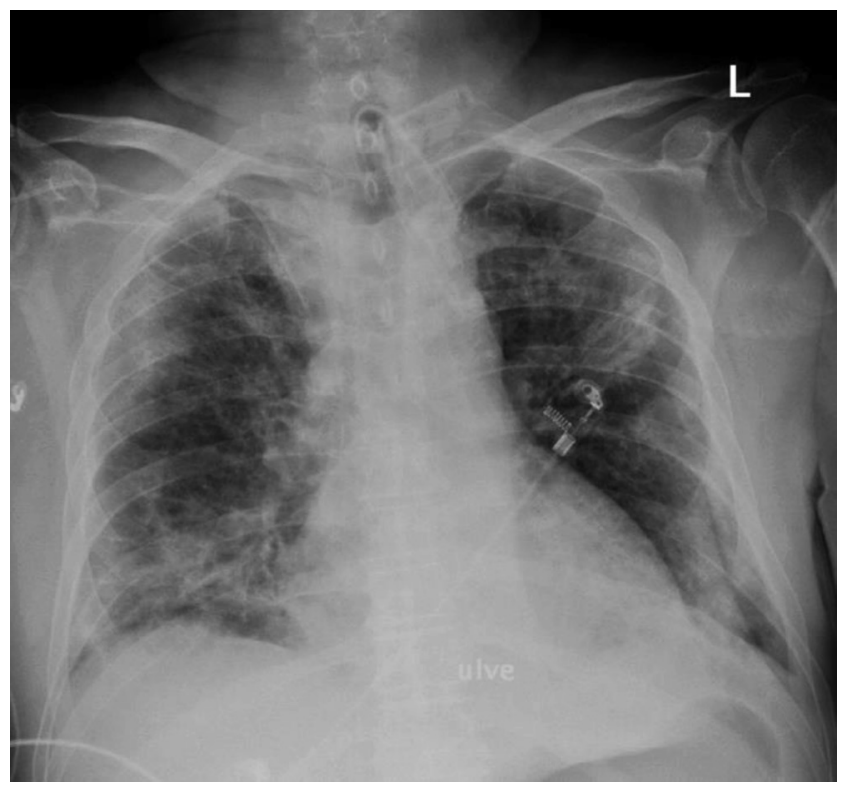

5. ábra | Jelentős javulás a mellkasfelvételen az elbocsátáskor

A károsodott szerv gyógyulásának feltétele az érintett szerv részleges vagy teljes nyugalomba helyezése. ARDSben a tüdő további károsodását mérséklő alacsony légzési térfogatú vagy alacsony csúcsnyomású [18], illetve újabban az alacsonyabb 'driving' nyomást célzó lélegeztetési irányelvek [19] javítják a kimenetelt. A tüdő teljes nyugalomba helyezése a szervezet egészének oxigénellátási igénye miatt, az ECMO-technika alkalmazásáig nem volt lehetséges. Intraoperatív tapasztalataink alapján tudjuk, hogy a tüdő teljes kollapszusa esetén is lehetséges VV ECMO-val kielégítő oxigenizációt biztosítani. A tartós tüdőkollapszus esetleges káros következményei még nem tisztázottak. 


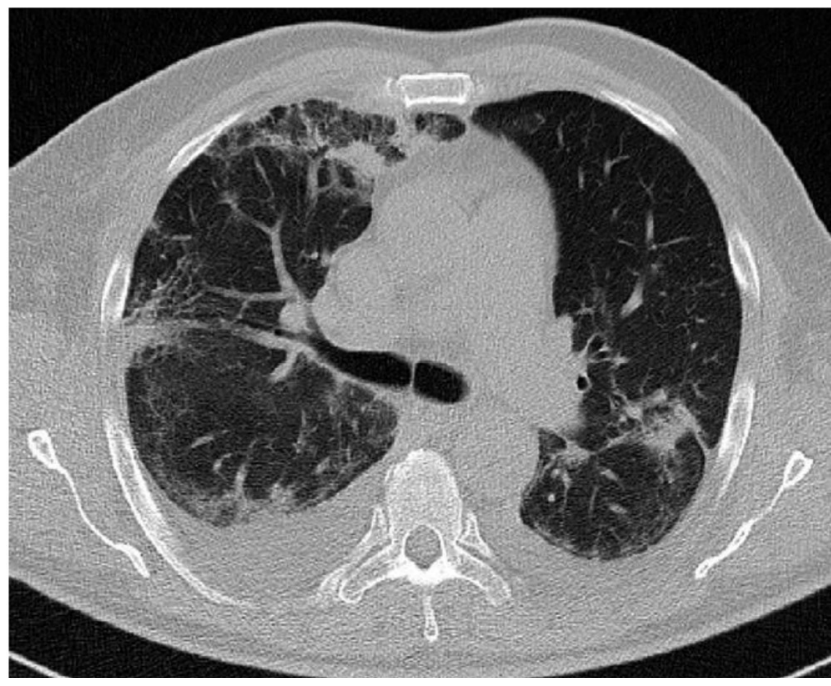

6. ábra

| A javulás a mellkasi CT-n is látható

Az ELSO ajánlása szerint megfontolandó az ECLSterápia hypoxiás légzési elégtelenség esetén, ha a várható mortalitás meghaladja az 50\%-ot, és indikált, ha meghaladja a $80 \%$-ot [16].

Tapasztalatok alapján a várható mortalitás meghaladja az 50\%-ot, ha a $\mathrm{PaO}_{2} / \mathrm{FiO}_{2}<150 \mathrm{Hgmm} \mathrm{FiO}_{2}>90 \%$-nál, és/vagy a Murray-pontszám 2-3 [20], az AOI-pontszám 60 [21]. 80\% vagy a feletti a várható mortalitás, amennyiben a $\mathrm{PaO}_{2} / \mathrm{FiO}_{2}<100 \mathrm{Hgmm} \mathrm{FiO}_{2}>90 \%$-nál, és/vagy a Murray-pontszám 3-4 [20], az AOI-pontszám >80 [21], az APPS >8 [22], 6 órát meg nem haladó optimális ellátás ellenére.

Megfontolandó az ECMO továbbá, ha szén-dioxidretenció áll fenn magas belégzésvégi nyomású (Pplat>30 vízcm) gépi lélegeztetés mellett, súlyos légáteresztésnél, tüdőtranszplantációs várólistára helyezett beteg légzési elégtelenségénél, valamint hirtelen kialakuló keringési, légzési elégtelenségben (masszív tüdőembólia, légút elzáródása).

Abszolút kontraindikáció nincs, de relatív kontraindikációként értékelhetők azok az állapotok, amelyek fennállása esetén - az eddigi tapasztalatok alapján - a kimenetelben nem várható javulás. Ilyen a 7 napot meghaladó lélegeztetés $\mathrm{FiO}_{2}>90 \%$-kal, Pplat>30 vízcm-rel; súlyos immunszuppresszió (abszolút granulocytaszám <400/ $\mathrm{mm}^{3}$ ); friss intracranialis vérzés. Megfontolandó a terápia súlyos társbetegség - mint korábbi kiterjedt központi idegrendszeri károsodás, malignus betegség végstádiuma; vérzékenység - vagy előrehaladott biológiai életkor esetén.

A fentiek alapján betegünk esetében az ECMO-kezelés indikációja fennállt. Betegségét megelőzően fizikálisan terhelhető volt, antikoagulálásnak a kontraindikációja nem állt fenn. Malignitása, központi idegrendszeri károsodása nem volt. A súlyos ARDS-t potenciálisan reverzibilis, bakteriális tüdőgyulladás okozta. A gépi lélegeztetés meghaladta a 10 napot, de kritikus paraméterekre $\left(\mathrm{FiO}_{2}>1,0\right.$ és Pplat $>30$ vízcm $)$ csak az átvételét megelőző 36 órában volt szükség. VV ECMO mellett döntöttünk, bár az induláskor észlelt csökkent balkamrafunkció és emelkedett mPAP felvetette a venoarteriovenosus (V-AV) technika nyújtotta pozitív hemodinamikai támogatás szükségességét. Feltételezve, hogy a csökkent szívteljesítmény hátterében a súlyos hypoxia, a hypoxiás vascularis constrictio (HPV-reflex) és a magas csúcsnyomású lélegeztetés okozta intrathoracalis nyomásemelkedés áll, a légzési elégtelenség indikációjának megfelelően femorojugularis VV ECMO-val indultunk. Nem vetettük el a lehetôséget, hogy súlyosbodó szívelégtelenség esetén V-AV ECMO-ra térünk át. Esetünkben a VV ECMO által biztosított praepulmonalis oxigenizáció hatására a mPAP csökkent, a szív funkciója a kezelésünk 12 órája után javulást mutatott.

$\mathrm{Az}$ aerob metabolikus igények $\left(\mathrm{VO}_{2}\right)$ kielégítésének feltétele a megfelelő oxigénszállítás $\left(\mathrm{DO}_{2}\right)$. Egészséges emberben a $\mathrm{DO}_{2}$ az ötszöröse a felhasználásnak, ami igen nagy „extrakciós tartalékot” jelent. Tapasztalatok szerint háromszoros $\mathrm{DO}_{2} / \mathrm{VO}_{2}$ elégséges a megfelelő extrakcióhoz. Ha ez az érték 2 alá csökken, a metabolizmus anaerobbá válik. ECMO-kezelés esetében a szervezetet a membránoxigenátor és a még múködő tüdő látja el oxigénnel $\left(\mathrm{DO}_{2}\right.$-ECMO $+\mathrm{DO}_{2}$-beteg $)$. Ha a károsodás extrém, és a tüdő gázcseréje minimális, a VV ECMO egyedül is képes kielégíteni a szervezet oxigénigényét. $\mathrm{Az}$ artériás szaturáció általában 75-85\% $\left(\mathrm{PaO}_{2} 40-50\right.$ Hgmm), ami megtartott szívfunkció és hemoglobinszint mellett képes biztosítani az oxigénigény háromszorosát [23]. A VV ECMO-hoz nem szokott intenzív osztályos ellátók gyakran aggódnak a 90\% alatti szaturáció miatt, és növelik a lélegeztetés $\left(\mathrm{FiO}_{2}\right.$, Pplat) invazivitását, ezzel továbbra is fenntartva a VALI lehetőségét. A VV ECMO célja, hogy a kielégítő oxigénellátás mellett a beteg tüdő nyugalomba helyezhető legyen, funkciójának pótlásával ne tegyük ki károsodásnak! Az élettan alapvető ismerete, az $\mathrm{O}_{2}$-kínálat és -felhasználás rendszeres számítása, illetve az ellátók oktatása elengedhetetlen részét képezi a VV ECMO-kezelésnek.

Az első tüdőpótlásként használt ECLS (1972) óta az ECLS-terápia eszközparkja óriási technikai fejlődésen ment keresztül. A ma használatos membránok akár egy hónapos kezelést is lehetővé tesznek intolerábilis plazmavesztés nélkül. Az okklúziós pumpákat kiváltó centrifugálpumpák sejtkárosító hatása kisebb. A gyárilag egybeépített oxigenátor-pumpa-bevonatos csőrendszerek alkalmazása minimalizálja a trombózis, illetve a légembólia veszélyét, és felhasználóbaráttá teszi a készülékeket. Mindez - kiegészítve ágy melletti laborvizsgálatok lehetőségével, komplex monitorizálással - az ECLS-kezelést a kardiológiai centrumokon kívül az általános intenzív osztályos felhasználásra is alkalmassá teszi. Intézetünkben először kiterjesztett mellkasi mútétek intraoperatív támogatásához használtunk VV ECMO-t. A hazai tüdőtranszplantációs program kialakítása tette lehetővé, hogy eszközparkunk segítségével vállalhassunk - a konvencionális respirátorterápiára és az ARDS-ben alkalma- 
zott 'rescue' eljárásokra nem javuló - súlyos ARDS-s betegek kezelését. A közölt sikeres eset és az azóta kezelt súlyos légzési elégtelen betegek terápiája, valamint a tüdőtranszplantáció és a kiterjesztett mellkasi mútéti tapasztalataink alapján megfontolandónak tartjuk az ECMO-kezelés hazai indikációjának szélesítését. Egy esetleges következő influenza-világjárványra történő felkészülésnek - a 2009/2010-es $\mathrm{H}_{1} \mathrm{~N}_{1}$-járvány kapcsán megfogalmazott prevenciós feladatokon túl [24] - a hazai ECMO-háttér kialakítása, szervezése is feladata lehet.

Anyagi támogatás: A közlemény megírása, illetve a kapcsolódó kutatómunka anyagi támogatásban nem részesült.

Szerzői munkamegosztás: M. I., B. I.: A probléma felvetése, a kézirat megírása, végső kialakítása. B. T., K.-T. K., S. N.: Adatgyưjtés. E. J.: Ellenőrzés. B. I.: A probléma felvetése, a kézirat megírása. A cikk végleges változatát valamennyi szerző elolvasta és jóváhagyta.

Érdekeltségek: A szerzőknek nincsenek érdekeltségeik.

\section{Irodalom}

[1] Bellani G, Laffey JG, Pham T, et al. The LUNG SAFE study: a presentation of the prevalence of ARDS according to the Berlin Definition! Crit Care 2016; 20: 268.

[2] Bellani G, Laffey JG, Pham T, et al. Epidemiology, patterns of care, and mortality for patients with acute respiratory distress syndrome in intensive care units in 50 countries. JAMA 2016; 315: 788-800.

[3] Rubenfeld GD, Caldwell E, Peabody E, et al. Incidence and outcomes of acute lung injury. N Engl J Med. 2005; 353: 16851693.

[4] Ranieri VM, Rubenfeld GD, Thompson BT, et al., ARDS Definition Task Force. Acute respiratory distress syndrome: the Berlin Definition. JAMA 2012; 307: 2526-2533.

[5] Umbrello M, Formenti P, Bolgiaghi L, et al. Current concepts of ARDS: a narrative review. Int J Mol Sci. 2017; 18: 64.

[6] ECLS registry report, international summary. July, 2018. Available from: https://www.elso.org/Registry/Statistics/InternationalSummary.aspx [accessed: July 12, 2018].

[7] Combes A, Hajage D, Capellier G, et al. Extracorporeal membrane oxygenation for severe acute respiratory distress syndrome. N Engl J Med. 2018; 378: 1965-1975.

[8] Gattinoni L, Vasques F, Quintel M. Use of ECMO in ARDS does the EOLIA trial really help? Crit Care 2018; 22: 171.

[9] Hill JD, O'Brien TG, Murray JJ, et al. Prolonged extracorporeal oxygenation for acute post-traumatic respiratory failure (shocklung syndrome). N Engl J Med. 1972; 286: 629-634.

[10] Zapol WM, Snider MT, Hill JD, et al. Extracorporeal membrane oxygenation in severe acute respiratory failure. A randomised prospecitve study. JAMA 1979; 242: 2193-2196.

[11] Morris AH, Wallace CJ, Menlove RL, et al. Randomised clinical trial of pressure-controlled inverse ration ventilation and extracorporeal $\mathrm{CO}_{2}$ removal for adult respiratory distress syndrome. Am J Respir Crit Care Med. 1994; 149: 295-305.
[12] Peek GJ, Mugford M, Tiruvoipati R, et al. Efficacy and economic assessment of conventional ventilatory support versus extracorporeal membrane oxygenation for severe adult respiratory failure (CESAR): a multicentre randomised controlled trial. Lancet 2009; 374: 1351-1363.

[13] Treatment of acute lung injury and acute respiratory distress syndrome. Guideline by the Hungarian Ministry of Health. $[\mathrm{Az}$ Egészségügyi Minisztérium szakmai irányelve. Az akut tüdőkárosodás és az akut respirációs distressz szindróma kezelése.] Budapest, 2005. [Hungarian]

[14] Varga Cs, Lelovics Zs, Soós V, et al. Patient turnover in a multidisciplinary emergency department. [Betegforgalmi trendek multidiszciplináris sürgősségi osztályon.] Orv Hetil. 2017; 158: 811-822. [Hungarian]

[15] Fazekas L, Sax B, Hartyánszky I, et al. Mechanical circulatory support saves lives - three years' experience of the newly established assist device program at Semmelweis University. [A mechanikus keringéstámogatás életet ment - a műszívprogram első három évének tapasztalata a Semmelweis Egyetemen.] Orv Hetil. 2015; 156: 521-527. [Hungarian]

[16] ELSO Guidelines for Cardiopulmonary Extracorporeal Life Support. Extracorporeal Life Support Organization, Version 1.4 August 2017, Ann Arbor, MI, USA. Available from: www.elso.org

[17] Schmidt M, Bailey M, Sheldrake J, et al. Predicting survival after extracorporeal membrane oxygenation for severe acute respiratory failure. The Respiratory Extracorporeal Membrane Oxygenation Survival Prediction (RESP) score. Am J Respir Crit Care Med. 2014; 189: 1374-1382.

[18] Gattinoni L, Quintel M. How ARDS should be treated. Crit Care 2016; 20: 86

[19] Amato B, Meade O, Slutsky S, et al. Driving pressure and survival in the acute respiratory distress syndrome. N Engl Med. $2015 ; 372: 747-755$.

[20] Murray JF, Matthay MA, Luce JM, et al. An expanded definition of the adult respiratory distress syndrome. Am Rev Respir Dis. 1988; 138: 720-723.

[21] Dechert RE, Park PK, Bartlett RH. Evaluation of the oxygenation index in adult respiratory failure. J Trauma Acute Care Surg. 2014; 76: 469-473.

[22] Villar J, Ambrós A, Soler JA, et al., for the Stratification and Outcome of Acute Respiratory Distress Syndrome (STANDARDS) Network. Age, $\mathrm{PaO}_{2} / \mathrm{FiO}_{2}$, and plateau pressure score: a proposal for a simple outcome score in patients with the acute respiratory distress syndrome. Crit Care Med. 2016; 44: 13611369.

[23] Brogan TV, Lequier L, Lorusso R. (eds.) Extracorporeal life support: The ELSO Red Book. 5th edn. Extracorporeal Life Support Organization, 2017.

[24] Hajnal F, Busa Cs, Papp R, et al. The role of primary care professionals in preventive activities during epidemics. Focus group assessment of the management of flu pandemic in 2009/2010. [Az alapellátásban dolgozó orvosok és munkatársaik preventív szerepe járványok idején. Fókuszcsoportokra alapozott szakmapolitikai hatáselemzés a 2009/2010. évi $\mathrm{H}_{1} \mathrm{~N}_{1}$ influenzavilágjárvány tapasztalatairól.] Orv Hetil. 2017; 158: 523-532. [Hungarian] 